\title{
Availability of Mineral Nitrogen in Soil under Maize + Soybean Intercropping System
}

\author{
Pragya Pandey $^{1}$ and R.K. Bajpai ${ }^{2}$ \\ ${ }^{1}$ Krishi Vigyan Kendra, Bemetara (Chhattisgarh), India \\ ${ }^{2}$ Directorate of Research, Indira Gandhi Agricultural University, \\ Raipur (Chhattisgarh), India \\ *Corresponding author
}

\section{Keywords \\ Crop arrangement, Nutrient management, Ammonical nitrogen, Nitrate nitrogen}

\section{Article Info}

Accepted:

20 February 2019

Available Online:

10 March 2019

\section{A B S T R A C T}

This field experiment was conducted during the kharif season of 2014 and 2015 at the Indira Gandhi Krishi Vishwavidyalaya, Raipur (C.G) to find out the effect of crop arrangement and nutrient management on availability of nutrients under maize and soybean intercropping system. Treatments comprised of six cropping arrangements viz. sole maize $\left(\mathrm{C}_{1}\right)$, sole soybean $\left(\mathrm{C}_{2}\right)$, two replacement series of maize + soybean $\left(2: 2, \mathrm{C}_{3}\right.$ and $\left.2: 4, C_{4}\right)$, two additive series in which two rows $\left(C_{5}\right)$ and one row $\left(\mathrm{C}_{6}\right)$ of soybean were added in-between two rows of maize and four fertility levels viz. $125 \%$ recommended dose of fertilizer (RDF) $\left(\mathrm{F}_{1}\right), 100 \% \operatorname{RDF}\left(\mathrm{F}_{2}\right), 75 \% \operatorname{RDF}\left(\mathrm{F}_{3}\right)$ and $50 \% \operatorname{RDF}\left(\mathrm{F}_{4}\right)$. Two control plots; control ${ }_{1}$ and control ${ }_{2}$ (From the two additive series plots soybean rows were omitted and the space between paired row of maize were left fellow) were planted in order to calculate the amount of mineral nitrogen supplemented by soybean to maize. Results of this experiment show the higher availability of nutrients in soil under intercropping over sole plantation. Out of six crop arrangements 2:4 replacement series of maize and soybean showed the highest availability of $\mathrm{NH}_{4}{ }^{+}-\mathrm{N}$ and $\mathrm{NO}_{3}{ }^{-} \mathrm{N}$ in soil and this was closely followed by maize + soybean 2:2 crop arrangement. However, the lowest availability of mineral nitrogen was observed from the sole soybean. Among different nutrient management the highest and lowest availability of aforesaid nutrients were reported in the treatment fertilized with $125 \%$ and $50 \% \mathrm{RDF}$, respectively. Intercropped treatments exhibited 10.76 and 8.39 per cent higher availability of $\mathrm{NH}_{4}{ }^{+} \mathrm{N}$ and 13.13 and 7 per cent higher availability $\mathrm{NO}_{3}{ }^{-} \mathrm{N}$ in soil in comparison to $\mathrm{control}_{1}$ and control $_{2}$, respectively. Around $17.09 \mathrm{~kg} \mathrm{ha}^{-1}$ higher available mineral nitrogen $\left(\mathrm{NH}_{4}{ }^{+}-\mathrm{N}+\mathrm{NO}_{3}{ }^{-} \mathrm{N}\right)$ was reported under intercropping treatments than control plots. This additional amount of available $\mathrm{NH}_{4}{ }^{+}-\mathrm{N}$ and $\mathrm{NO}_{3}{ }^{-} \mathrm{N}$ was supplied by the soybean through biological nitrogen fixation.

\section{Introduction}

Economic constraints among small scale farmers in India limit sole inorganic fertilizer use. Further, the use of fertilizer, pesticides and various synthetic chemicals leads to the degradation of cultivable land and natural resources. Thus it is necessary to find 
additional sources of $\mathrm{N}$ that would embrace the smallholder socio-economic status. Cereal + grain legume intercropping is one of them. Growing of cereal with grain legume has not only gives higher yield but also has the potential to address the soil nutrient depletion on smallholder farms (Sanginga and Woomer, 2009). Maize and soybean are promising crops in aerable lands of Chhattisgarh besides rice as main crop in medium and low land situation. Intercropping of legumes in maize was found productive economically and energetically viable (Pandey et al., 2003) compared to either of the sole crops. Soybean is considered as an ideal crop for intercropping with maize owing to its comparative tolerance for shade and drought, efficient light utilization and less competitiveness for soil moisture (Wright et al., 1988).

Intercropping is a viable agronomic practice for stepping up the production of these crops from a unit of land besides sustaining the soil health through biological nitrogen fixation by soybean during a cropping period. Sustainable production of these crops requires a careful management of all nutrient sources available in a farm, particularly in maize based cropping systems. These include inorganic fertilizers and integration of legume crops in cereal based mono cropping (Wakene et al., 2007). Maize being an exhaustive crop requires high quantity of fertilizers, particularly nitrogenous. In intercropping systems, legumes can provide $\mathrm{N}$ for intercropped cereals through $\mathrm{N}$ transfer. Thus being a legume crop soybean is capable of supplying nitrogen for its growth and intercropped cereals through symbiotic nitrogen fixation, and hence reduces the need for expensive and environment polluting nitrogen fertilizer (Ning et al., 2012).

Transformation of added nitrogen through fertilizers, manures or biological nitrogen fixation into different forms of nitrogen in soil and their availability to crops depends on soil properties and nature of nitrogen sources added to soils. According to the research reports, more than 90 per cent of nitrogen in the soil is present in organic form and concentrations of inorganic form viz., nitrate nitrogen and ammonical nitrogen in soil at any given time is influenced by several soil factors. So to maintain the higher availability of nutrients in order to obtain the optimum yield from the intercropping system, there is need to take care of different types of competitions between the intercrops. Therefore, this experiment is an attempt to study the proper arrangement of component crops in order to avoid limitation of reduced plant population of base crop under traditional intercropping system and a careful management of all nutrient sources which includes inorganic fertilizers as well as the biologically fixed nitrogen provided by soybean to maize so that higher production unit $^{-1}$ of land could be achieved.

\section{Materials and Methods}

Field experiment was conducted during the kharif season (July to October) of 2014 and 2015 at the Instructional cum Research Farm, Indira Gandhi Krishi Vishwavidyalaya, Raipur situated in central parts of Chhattisgarh and lies at latitude, longitude and altitude of $21^{\circ} 4^{\prime}$ $\mathrm{N}, 81^{\circ} 35^{\prime} \mathrm{E}$ and 290.20 metres above mean sea level, respectively. The hybrid maize variety Hishell and soybean variety Jawahar Soybean 97-52 (JS 97-52) were used in the experiment. Soil of experimental site was caly (Vertisol) with neutral $\mathrm{pH}$ (7.50) and 0.26 dSm EC. Soil was low in nitrogen $(175.61 \mathrm{~kg}$ $\left.\mathrm{ha}^{-1}\right)$ and phosphorus (10.74 $\left.\mathrm{kg} \mathrm{ha}{ }^{-1}\right)$ and potassium availability was medium $(330.74 \mathrm{~kg}$ $\left.\mathrm{ha}^{-1}\right)$. The experiment was laid out in Factorial Randomised Block Design with one additional plot design. There were 3 replications and all of them were divided into $24+2$ experimental treatments and each treatment was applied to a plot had an area of $38.4 \mathrm{~m}^{2}$. Maize and 
soybean were spaced at a spacing of $60 \times 20$ $\mathrm{cm}^{2}$ and $5 \times 30 \mathrm{~cm}^{2}$, respectively. Treatments comprised of six cropping arrangements viz. sole maize $\left(\mathrm{C}_{1}\right)$, sole soybean $\left(\mathrm{C}_{2}\right)$, maize + soybean in 2:2 $\left(\mathrm{C}_{3}\right)$ and 2:4 $\left(\mathrm{C}_{4}\right)$ rows in replacement series and two additive series (two rows of soybean $\left(\mathrm{C}_{5}\right)$ and one row of soybean $\left(\mathrm{C}_{6}\right)$ planted in-between two rows of maize and four fertility levels viz. $125 \%$ recommended dose of fertilizer (RDF) $\left(\mathrm{F}_{1}\right)$, $100 \% \mathrm{RDF}\left(\mathrm{F}_{2}\right), 75 \% \mathrm{RDF}\left(\mathrm{F}_{3}\right)$ and $50 \% \mathrm{RDF}$ $\left(\mathrm{F}_{4}\right)$. Recommended dose of fertilizer used for maize was $110 \mathrm{~kg} \mathrm{~N}^{-1}, 60 \mathrm{P}_{2} \mathrm{O}_{5} \mathrm{~kg} \mathrm{ha}^{-1}$ and $40 \mathrm{~K}_{2} \mathrm{O} \mathrm{kg} \mathrm{ha}{ }^{-1}$ and for soybean was $20 \mathrm{~N} \mathrm{~kg}$ $\mathrm{ha}^{-1}, 60 \mathrm{P}_{2} \mathrm{O}_{5} \mathrm{~kg} \mathrm{ha}^{-1}$ and $40 \mathrm{~K}_{2} \mathrm{O} \mathrm{kg} \mathrm{ha}{ }^{-1}$. Analysis of availability of ammonium and nitrate nitrogen was done by Steam distillation method as suggested by Bremner and Keeney (1965). To find out the amount of nitrogen supplemented by soybean to maize we compared the mean availability of mineral nitrogen (Ammonium and nitrate) from 24 treatments and this was compared with control plots. For this comparison two control plots were taken in which the soybean rows planted in between paired maize rows (Under two additive series i.e. $2 \mathrm{M}+2 \mathrm{~S}$ and $2 \mathrm{M}+4 \mathrm{~S}$ ) were omitted and space occupied by the soybean rows were left fellow. So two paired row of maize (row x row spacing, $60 \mathrm{~cm}$ ) were planted at $90 \mathrm{~cm}$ distance in control ${ }_{1}$ and 150 $\mathrm{cm}$ distance in control $_{2}$. $100 \%$ RDF was applied to both the control plots. The experimental data were statistically analyzed for analysis of variance and test of significance as described by Gomez and Gomez (1984).

\section{Results and Discussion}

\section{Availability of nitrogen in soil}

Availability of nitrogen in soil was significantly influenced by the treatments imposed. Observations were taken at periodic interval of 20 days till harvest i.e. at 20, 40,
60, 80 DAS and at harvest. Availability of the mineral nitrogen increase upto 60 DAS but after that till harvest decreasing trend was reported. This was due to the three reasons: (1) Side placement of fertilizer to the crops was done at the critical growth stages (between 40-60 DAS) of crop, application of fertilizer at this stage/duration has increased the availability of nutrients in soil (2) Maximum uptake of nutrients take place at major growth period of crop i.e. during 40-80 DAS and as the crop has already taken up the majority of nutrients from the soil during this time period, the availability of nutrient later on was decreased. (3) As the crop advances to harvesting, especially during 80 DAS to harvesting, the moisture level in the soil of the field goes down and this drastically reduces the availability of ammonium nitrogen. This is in agreement with Li et al., (2001).

\section{Availability of ammonium-N}

Among six crop arrangements, 2 maize +4 soybean replacement series $\left(\mathrm{C}_{4}\right)$ showed the highest value of available $\mathrm{NH}_{4}{ }^{+}-\mathrm{N}$ from 20 DAS till harvest except at 80 DAS when paired row replacement series $\left(\mathrm{C}_{3}\right)$ recorded the highest available $\mathrm{NH}_{4}{ }^{+}-\mathrm{N}$ in soil (Table 1). However, these two treatments were reported at par at all the observational stages except at 60 DAS. This finding is in line with the result explained by Matusso et al., (2014).

On the other hand, comparatively lower availability $\mathrm{NH}_{4}{ }^{+}-\mathrm{N}$ was observed from sole maize $\left(\mathrm{C}_{1}\right)$ and sole soybean $\left(\mathrm{C}_{2}\right)$. Further sole soybean $\left(\mathrm{C}_{2}\right)$ recorded the lowest value throughout the crop growth period. Higher availability of $\mathrm{NH}_{4}{ }^{+}-\mathrm{N}$ in intercropping than sole planting is due to the contribution of biological nitrogen fixed by intercropped soybean in addition to the applied synthetic fertilizers. Among different nutrient management, treatments fertilized with $125 \%$ $\mathrm{RDF}\left(\mathrm{F}_{1}\right)$ and $50 \%$ RDF $\left(\mathrm{F}_{4}\right)$ showed 
significantly higher and lower value of available $\mathrm{NH}_{4}{ }^{+}-\mathrm{N}$, respectively, in soil over remaining nutrient managements. The reason behind this was increasing amount of nitrogen fertilizer application rates from $50 \%$ to $125 \%$ RDF. Kebeney et al., (2015) also reported the same.

\section{Availability of nitrate $-\mathrm{N}$}

Throughout the crop growth stage highest availability of $\mathrm{NO}_{3}{ }^{-} \mathrm{N}$ in soil was reported from $\mathrm{C}_{4}$ i.e. 2 maize +4 soybean intercropping system and this was found comparable with the additive series $\mathrm{C}_{5}$ (Two rows of soybean added in between two rows of maize) at all the observational stage except at - harvest. Increase in $\mathrm{NO}_{3}-\mathrm{N}$ content may be ascribed to nitrification of $\mathrm{NH}_{4}-\mathrm{N}$ to $\mathrm{NO}_{3}-\mathrm{N}$ by soil microorganisms (Santhy et al., 1998).

On the other hand, the lowest available $\mathrm{NO}_{3}{ }^{-}$ $\mathrm{N}$ in soil was recorded from sole soybean $\left(\mathrm{C}_{2}\right)$, however, this found comparable with sole maize throughout the crop growth period (Table 2). Regarding nutrient management maximum available $\mathrm{NO}_{3}{ }^{-} \mathrm{N}$ in soil was obtained under highest amount of fertilizer applied soil i.e. $125 \%$ RDF. With the decrease in fertility levels from $125 \% \mathrm{RDF}$ to $50 \%$ RDF significant decrease in $\mathrm{NO}_{3}{ }^{-} \mathrm{N}$ availability in soil was reported.

\section{Mineral nitrogen (Ammonium and nitrate) supplemented by soybean to maize}

Legumes enrich soil by fixing the atmospheric nitrogen converting it from an inorganic form to forms that are available for plants uptake. Biological fixation of atmospheric nitrogen can replace nitrogen fertilization wholly or in part.

Biological nitrogen fixation is the major source of nitrogen in legume-cereal mixed cropping systems when nitrogen fertilizer is limited. Moreover, because inorganic fertilizers have much environmental damage such as nitrate pollution, legumes grown in intercropping are regarded as a sustainable and alternative way of introducing $\mathrm{N}$ into lower input agro ecosystems (Fustec et al., 2010).

In Table 3 mean data related to the availability of $\mathrm{NH}_{4}{ }^{+}-\mathrm{N}$ (mg kg-1 of soil) of the 24 treatment combinations of crop arrangements and nutrient managements (Rest) is presented which were compared to the two control treatments i.e. control $_{1}$ (Paired row maize planted at $60 \mathrm{~cm}$ and spacing between two pairs of rows was $90 \mathrm{~cm}+100 \%$ RDF) and control $_{2}$ (Paired row maize were planted at 60 $\mathrm{cm}$ and spacing between two pairs was $150 \mathrm{~cm}$ $+100 \% \mathrm{RDF}$ ).

In case of availability of $\mathrm{NH}_{4}{ }^{+}-\mathrm{N}$, non significant difference between rest and controls were reported at 20 DAS, but later on mean availability of $\mathrm{NH}_{4}{ }^{+} \mathrm{N}$ in soil of 24 treatments (Combinations of the crop arrangement and nutrient management) showed significant higher availability over both the controls (Table 3). Significant variation in the availability of $\mathrm{NH}_{4}{ }^{+}-\mathrm{N}$ in soil of control $_{1}$ and rest (Mean availability from 24 treatments) was recorded at all the observational stages.

But in case of $\mathrm{control}_{2}$, the availability of $\mathrm{NH}_{4}{ }^{+}-\mathrm{N}$ was found comparable with rest upto 40 DAS of crop growth and afterward till harvest the mean availability from the 24 treatments i.e. rest was reported significantly superior over control $_{2}$. But the highest availability of $\mathrm{NO}_{3}{ }^{-} \mathrm{N}$ in soil was reported from rest and this was followed by $\mathrm{control}_{2}$ (two paired row of maize spaced at $60 \mathrm{~cm}$ planted at a distance of $150 \mathrm{~cm}$ with each other) throughout the crop growth stage (Table 4). Osunde et al., (2004) also found higher nitrogen availability in intercropping and observed that the proportion of nitrogen 
derived from atmosphere fixation was about 40 percent in the intercropped soybean and 30 percent in the sole crop without the addition of fertilizer.

At harvest stage the 6.63 and $5.17 \mathrm{~kg}$ higher mean availability of $\mathrm{NH}_{4}{ }^{+}-\mathrm{N} \mathrm{ha}^{-1}$ was reported from the intercroping in comparison to control $_{1}$ and control 2 , respectively and in case of $\mathrm{NO}_{3}{ }^{-} \mathrm{N}$ this additional availability was 16.47 and $9.02 \mathrm{~kg} \mathrm{ha}^{-1}$ higher than control $_{1}$ and control $_{2}$, respectively.

Between the two controls, control ${ }_{2}$ proved to be more advantageous over control $_{1}$ and showed higher availability of mineral nitrogen in soil, however the difference between the two controls was non-significant at all the observational stages.

\section{Grain yield}

The grain yield was significantly influenced by different cropping system and nutrient levels. Among crop arrangements $\mathrm{C}_{3}$, Maize + soybean $(2: 2$, replacement series) produced significantly higher grain yield over rest of the crop arrangement (Table 5).

This was followed by additive series $\mathrm{C}_{5}$ (two rows of soybean added in between two rows of maize). The significantly lower producer was sole soybean. Under maize + soybean intercropping systems, soybean yield tends to be lower and maize yield tends to be higher (Ghaffarzaeh et al., 1994). The increase in the total grain production of intercropping system obviously was the result of additional yield of soybean as bonus by utilization of inter-row space of maize crop.

Table.1 Availability of NH4+- N in soil as influenced by the crop arrangement and nutrient management under maize + soybean intercropping system (Mean data of 2014 and 2015)

\begin{tabular}{|c|c|c|c|c|c|}
\hline \multicolumn{6}{|c|}{ Available ammonium-N (mg kg ${ }^{-1}$ of soil) } \\
\hline Treatments & 20 DAS & 40 DAS & 60 DAS & $80 \mathrm{DAS}$ & At harvest \\
\hline \multicolumn{6}{|l|}{$\begin{array}{l}\text { Crop } \\
\text { arrangement }\end{array}$} \\
\hline $\mathbf{C}_{1}$ & 16.61 & 31.66 & 44.43 & 34.44 & 26.71 \\
\hline $\mathbf{C}_{2}$ & 16.20 & 30.24 & 43.15 & 33.10 & 26.13 \\
\hline $\mathbf{C}_{3}$ & 17.45 & 33.13 & 46.07 & 37.18 & 28.09 \\
\hline $\mathbf{C}_{4}$ & 17.66 & 33.75 & 47.22 & 36.68 & 28.86 \\
\hline $\mathbf{C}_{5}$ & 17.20 & 32.54 & 45.52 & 35.72 & 27.55 \\
\hline $\mathbf{C}_{6}$ & 16.91 & 31.87 & 44.45 & 35.00 & 27.14 \\
\hline SEm \pm & 0.21 & 0.50 & 0.63 & 0.44 & 0.40 \\
\hline $\mathrm{CD}(\mathrm{P}=\mathbf{0 . 0 5})$ & 0.50 & 1.18 & 1.49 & 1.05 & 0.94 \\
\hline \multicolumn{6}{|l|}{$\begin{array}{l}\text { Nutrient } \\
\text { management }\end{array}$} \\
\hline $\mathbf{F}_{1}$ & 19.00 & 35.65 & 49.57 & 38.83 & 30.34 \\
\hline $\mathbf{F}_{2}$ & 17.33 & 32.93 & 46.43 & 35.97 & 28.32 \\
\hline $\mathbf{F}_{3}$ & 16.24 & 31.14 & 43.66 & 34.02 & 26.40 \\
\hline $\mathbf{F}_{4}$ & 15.43 & 29.07 & 40.89 & 32.59 & 24.58 \\
\hline SEm \pm & 0.17 & 0.40 & 0.51 & 0.36 & 0.32 \\
\hline $\mathrm{CD}(\mathrm{P}=\mathbf{0 . 0 5})$ & 0.41 & 0.96 & 1.22 & 0.86 & 0.77 \\
\hline
\end{tabular}


Table.2 Availability of NO3-- $\mathrm{N}$ in soil as influenced by the crop arrangement and nutrient management under maize + soybean intercropping system (Mean data of 2014 and 2015)

\begin{tabular}{|c|c|c|c|c|c|}
\hline \multicolumn{6}{|c|}{ Available ammonium-N (mg kg ${ }^{-1}$ of soil) } \\
\hline Treatments & $20 \mathrm{DAS}$ & 40 DAS & 60 DAS & 80 DAS & At harvest \\
\hline \multicolumn{6}{|l|}{$\begin{array}{l}\text { Crop } \\
\text { arrangement }\end{array}$} \\
\hline $\mathbf{C}_{1}$ & 53.50 & 66.26 & 92.48 & 73.00 & 55.04 \\
\hline $\mathbf{C}_{2}$ & 53.11 & 65.60 & 92.47 & 72.33 & 54.43 \\
\hline $\mathbf{C}_{3}$ & 56.13 & 68.54 & 95.40 & 75.31 & 56.24 \\
\hline $\mathrm{C}_{4}$ & 57.41 & 69.52 & 96.97 & 76.78 & 57.52 \\
\hline $\mathrm{C}_{5}$ & 55.25 & 67.87 & 94.28 & 74.49 & 55.97 \\
\hline $\mathrm{C}_{6}$ & 54.45 & 66.67 & 93.66 & 73.51 & 55.19 \\
\hline SEm \pm & 0.66 & 0.55 & 0.73 & 0.73 & 0.43 \\
\hline $\mathrm{CD}(\mathrm{P}=\mathbf{0 . 0 5})$ & 1.56 & 1.29 & 1.73 & 1.73 & 1.02 \\
\hline \multicolumn{6}{|l|}{$\begin{array}{l}\text { Nutrient } \\
\text { management }\end{array}$} \\
\hline $\mathbf{F}_{1}$ & 59.65 & 73.37 & 101.67 & 80.36 & 60.49 \\
\hline $\mathbf{F}_{2}$ & 56.20 & 68.66 & 96.66 & 76.22 & 56.85 \\
\hline $\mathbf{F}_{3}$ & 53.06 & 65.28 & 91.46 & 71.61 & 54.00 \\
\hline $\mathbf{F}_{4}$ & 51.00 & 62.34 & 87.05 & 68.75 & 51.58 \\
\hline SEm \pm & 0.54 & 0.45 & 0.59 & 0.59 & 0.35 \\
\hline $\mathrm{CD}(\mathrm{P}=\mathbf{0 . 0 5})$ & 1.27 & 1.06 & 1.41 & 1.41 & 0.83 \\
\hline
\end{tabular}

$\mathrm{C}_{1}$-Sole maize, $\mathrm{C}_{2}$-Sole soybean, $\mathrm{C}_{3}$-Maize+ soybean, 2:2, $\mathrm{C}_{4}$-Maize+ soybean, 2:4, $\mathrm{C}_{5}$ - Two rows of soybean planted in between two rows of maize, $\mathrm{C}_{6}$-One row of soybean planted in between two rows of maize, $\mathrm{F}_{1}-125 \% \mathrm{RDF}, \mathrm{F}_{2}$ $100 \%$ RDF, $\mathrm{F}_{3}-75 \%$ RDF, $\mathrm{F}_{4}-50 \%$ RDF

Table.3 Status of NH4+ - N in the soil under maize + soybean intercropping system and control plots (Mean data of 2014 and 2015)

\begin{tabular}{|c|c|c|c|c|c|}
\hline \multicolumn{6}{|c|}{ Available ammonium- $\mathrm{N}$ ( $\mathrm{mg} \mathrm{kg}^{-1}$ of soil) } \\
\hline $\begin{array}{l}\text { Control } \\
\text { vs. rest }\end{array}$ & 20 DAS & 40 DAS & 60 DAS & 80 DAS & At harvest \\
\hline Rest & 17.00 & 32.20 & 45.14 & 35.35 & 27.41 \\
\hline Control $_{1}$ & 16.53 & 28.95 & 41.40 & 32.03 & 24.46 \\
\hline SEm \pm & 0.43 & 1.01 & 1.28 & 0.91 & 0.82 \\
\hline SEd \pm & 0.60 & 1.40 & 1.78 & 1.25 & 1.14 \\
\hline $\begin{array}{l}\text { CD } \\
(P=0.05)\end{array}$ & NS & 2.82 & 3.57 & 2.52 & 2.28 \\
\hline Control $_{2}$ & 17.29 & 31.11 & 41.67 & 32.56 & 25.11 \\
\hline SEm \pm & 0.43 & 1.30 & 1.30 & 0.90 & 0.81 \\
\hline SEd \pm & 0.59 & 1.42 & 1.25 & 1.25 & 1.12 \\
\hline $\mathrm{CD}(\mathrm{P}=\mathbf{0 . 0 5})$ & NS & 2.87 & 3.61 & 2.50 & 2.25 \\
\hline Con $_{1}$ vs.Con 2 & NS & NS & NS & NS & NS \\
\hline
\end{tabular}


Table.4 Status of NO3- - N in soil under maize + soybean intercropping system and control plots (Mean data of 2014 and 2015)

\begin{tabular}{|c|c|c|c|c|c|}
\hline \multicolumn{6}{|c|}{ Available nitrate-N (mg kg ${ }^{-1}$ of soil) } \\
\hline Control vs. rest & $20 \mathrm{DAS}$ & $40 \mathrm{DAS}$ & $60 \mathrm{DAS}$ & 80 DAS & At harvest \\
\hline Rest & 54.98 & 67.41 & 94.21 & 74.24 & 55.73 \\
\hline Control $_{1}$ & 49.96 & 55.64 & 81.12 & 60.37 & 48.41 \\
\hline SEm \pm & 1.34 & 1.11 & 1.48 & 1.50 & 0.87 \\
\hline SEd \pm & 1.86 & 1.54 & 2.05 & 2.06 & 1.21 \\
\hline $\mathrm{CD}(\mathrm{P}=\mathbf{0 . 0 5})$ & 3.74 & 3.10 & 4.13 & 4.14 & 2.43 \\
\hline Control $_{2}$ & 51.16 & 59.95 & 89.48 & 60.69 & 51.72 \\
\hline SEm \pm & 1.12 & 0.87 & 1.49 & 1.38 & 0.94 \\
\hline SEd \pm & 1.55 & 1.21 & 2.06 & 1.91 & 1.30 \\
\hline $\mathrm{CD}(\mathrm{P}=\mathbf{0 . 0 5})$ & 3.12 & 2.43 & 4.14 & 3.84 & 2.61 \\
\hline $\operatorname{Con}_{1}$ vs.Con 2 & NS & NS & NS & NS & NS \\
\hline
\end{tabular}

Rest- Mean availability of $\mathrm{NH}_{4}{ }^{+}-\mathrm{N}$ in soil from 24 combination of crop arrangement and nutrient management, Control $_{1}$ - Paired row planting of maize at $60 \mathrm{~cm}$ and spacing between two pairs was $90 \mathrm{~cm}+100 \%$ RDF, $\mathrm{Control}_{2}$ Paired row planting of maize at $60 \mathrm{~cm}$ and spacing between two pairs was $150 \mathrm{~cm}+100 \%$ RDF

Table.5 Effect of cropping arrangement and fertility levels on light interception (\%) and grain maize equivalent yield (q ha-1) of maize under maize + soybean intercropping system (Mean data of 2014 and 2015)

\begin{tabular}{|l|c|}
\hline \multicolumn{1}{|c|}{ Treatment } & $\begin{array}{c}\text { Grain maize equivalent yield } \\
\left(\mathrm{q} \mathrm{ha}^{-1}\right)\end{array}$ \\
\cline { 2 - 2 } & \\
\hline Cropping arrangement & 60.30 \\
\hline $\mathrm{C}_{1}$ (Sole maize) & 27.80 \\
\hline $\mathrm{C}_{2}$ (Sole soybean) & 71.90 \\
\hline $\mathrm{C}_{3}$ (Maize + soybean, 2:2) & 49.00 \\
\hline $\mathrm{C}_{4}$ (Maize + Soybean, 2:4) & 64.60 \\
\hline $\mathrm{C}_{5}$ (Two row of soybean planted in between two row of maize) & 63.20 \\
\hline $\mathrm{C}_{6}($ One row of soybean planted in between two row of maize $)$ & 0.84 \\
\hline SEm \pm & 2.36 \\
\hline CD $(\mathrm{P}=0.05)$ & \\
\hline Nutrient management & 62.50 \\
\hline $\mathrm{F}_{1}(125 \%$ RDF $)$ & 59.10 \\
\hline $\mathrm{F}_{2}(100 \%$ RDF $)$ & 53.70 \\
\hline $\mathrm{F}_{3}(75 \% \mathrm{RDF})$ & 49.20 \\
\hline $\mathrm{F}_{4}(50 \% \mathrm{RDF})$ & 0.69 \\
\hline $\mathrm{SEm} \pm$ & 1.93 \\
\hline $\mathrm{CD}(\mathrm{P}=0.05)$ & \\
\hline
\end{tabular}


Htet et al., (2016) indicated that, legume contribution to corn in mixtures was significant and increased the total biomass yield of mixtures. Our findings are in accordance with these researches. Among four nutrient levels, the grain yield obtained from $F_{1}(125 \% \quad R D F)$ was highest and significantly superior because of the superior yield attributing characters. Panhwar et al., (2004) concluded that fertilizer levels exhibited highly significant effect on grain yield of maize. However, the lowest grain yield was reported from the treatment with $50 \% \operatorname{RDF}\left(\mathrm{F}_{4}\right)$.

\section{References}

Bremner, J.M. and Keeney, D.R. 1965. Steam distillation methods for determination of ammonium, nitrate, and nitrite. Anal. Chem. Acta., 32: 485-495.

Fustec, J., Lesuffleur, F., Mahieu, S. and Cliquet, J. B. 2010. Nitrogen rhizodeposition of legumes- A Review. Agron Sustain Dev, 30: 57-66.

Ghaffarzaeh, M., Prechac, F.G. and Cruse, R.M. 1994. Grain yield response of corn, soybean and oat grown under strip intercropping systems. Am. Altern. Agric., 9:171-177.

Gomez, K.A. and Gomez, A.A. 1984. Statistical procedure for agricultural research. John Wiley and Sons Publication 2nd edition. New York, p. 680.

Htet, M.N., Soomro, N.S. and Jiang, b.O.H. 2016. Effect of Intercropping of maize (Zea mays L.) and soybean (Glycine max L.) on green forage yield and quality evaluation. IOSR Journal of Agriculture and Veterinary Science (IOSR-JAVS), 9(12):59-63.

Kebeney, S. J., Semoka, J. M. R., Msanya, B. M., Ng'etich, W. K. and Chemei, D. K. 2015. Effects of nitrogen fertilizer rates and soybean residue management on nitrate nitrogen in sorghum-soybean intercropping system. Internation//al Journal of Plant and Soil Science, 4(3):212-229.

Li, L., Sun, J., Zhang, F., Li, X., Yang, S., and Rengel, Z. 2001. Wheat-maize or wheat-soybean strip intercropping I yield advantage and interspecific interaction on nutrients. Field Crop Res., 71: 123-137.

Matusso, J.M.M. 2014. Effects of maize (Zea maysL.)- soybean (Glycine $\max \mathrm{L}$. Merrill) Intercropping patterns on yields and soil properties in two contrasting sites of Embu and Counties, Kenya. $\mathrm{PhD}$ thesis, Kenyatta University, Kenya, p.29

Ning T, Zheng Y, Han H, Jiang G, Li Z. 2012. Nitrogen Uptake, Biomass Yield and Quality of Intercropped Spring- and Summer-Sown Maize at Different Nitrogen Levels in the North China Plain. Biomass Bioenergy, 47:91-98.

Osunde, A.O., Tsado, P.A., Bala, A. and Sanginga, N. 2004. Productivity of maize promiscuous soybean intercrop as affected by the fertilizer in the Southern Guinea Sawanna Zone of Nigeria. West African Journal of Applied Ecology, 5: 51-62.

Pandey, Z.B., Bharati, Y. and Mishra, S.S. 2003. Effect of maize (Zea mays)-based intercropping systems on maize yield and associated weeds under rainfed condition. Indian Journal of Agronomy, 48(1): 30-33.

Panhwar, M.A., Memon, F.H., Kalhoro, M.A. and Soomro, M.I. 2004. Performance of maize in intercropping system with soybean under different planting pattern and nitrogen levels. Journal of Applied Sciences, 4(2): 201-204.

Sanginga N and Woomer P.L. 2009. Integrated soil Fertility management in Africa: Principles, Practices and Development Process. (Eds.). Tropical 
Soil Biology and Fertility Institute of the International Centre for Tropical Agriculture. Nairobi, pp. 263.

Santhy, P., Jayasree, S., Muthuvel, P. and Selvi, D. 1998. Long-term fertilizer experiments. Status of N, P and K fractions in soil. J. Indian Soc. Soil Sci. 46: 395-98.

Singh, M., Singh, P. and Nepalia, V. 2005. Integrated weed management studied in maize based intercropping system. Indian Journal of Weed Science 37(34): 205-208.

Wakene, N., Fite G., Abdena and Birhanu, D.
2007. Integrated use of organic and inorganic fertilizers for maize production. In utilization diversity in land use systems: Sustainable and organic approaches to meet human needs. Conference Tropentag, October 9-12, Witzenhousen, Kassel, Germany.

Wright, G.C., Smith, C.J. and Nelson, I.B. 1988. Growth and yield of soybean under wet soil culture and conventional furrow irrigation in South-Eastern Australia. Irrigation Science, 9: 127192.

\section{How to cite this article:}

Pragya Pandey and Bajpai, R.K. 2019. Availability of Mineral Nitrogen in Soil under Maize + Soybean Intercropping System. Int.J.Curr.Microbiol.App.Sci. 8(03): 2246-2254. doi: https://doi.org/10.20546/ijcmas.2019.803.268 